\title{
The contemporary innovation enterprise management development \\ trend and countermeasures thinking
}

\author{
LingLing Yu, JianBao Chang \\ Nanchang Institute of Technology, Nanchang, Jiangxi, 330044
}

Keywords management innovation of the knowledge economy

\begin{abstract}
the current under the background of knowledge economy era, the focus of enterprise competition has turned to human resource management in terms of competition, puts forward new requirements to the enterprise human resources management. Give full play to the role of human resources, it is necessary to reform the traditional personnel management, with the development of The Times. Therefore, enterprises can depend on the characteristics of the human resource management in knowledge economy age, requires innovation motivation, analyzes the present situation of human resource management in knowledge economy age, knowledge economy era development direction and countermeasures of human resources management innovation, promote enterprise human resources management innovation work.
\end{abstract}

\section{Introduction}

With the rapid development of market economy and the coming of the information age, the pace of economic development is becoming more and more quickly, the competition between enterprises is increasingly fierce, want to have a place in the fierce market competition, companies are also began to learn the new management concept and management methods, in the learning process of gradually found that human resource is the first resource of the enterprise, 21st century international competition will be more and more fierce, especially the talent competition, the enterprise human resources management is undoubtedly a great challenge. In human resources management system, performance management occupies the core position, which makes the enterprise managers pay more attention to performance management work, because the advanced performance management system plays an important role on the implementation of the enterprise strategic target.

\section{Under the background of knowledge economy era of human resource management innovation, the analysis of the characteristics of the requirements}

Enterprises should change the original force resources management system management method, strengthen the humanistic idea, promote the healthy growth of talents, give full play the role of talent; Fully arouse all kinds of talent, initiative and creative passion. Is beneficial to the talent system, growth mechanism, and the environment, to fully play their talent and potential value; Reform of all kinds of talent evaluation, establishes the performance evaluation index system as the core of all kinds of talent, talent open, equality and dispatch mechanism choice and competition and performance.

Knowledge economy era, technology management is the core competitive edge of the support, the talented person, become the traditional concept of science, the lack of advanced technology management, business simple, single function, lack of professional skills, a lack of competition and 
management means backward, low efficiency, and can not adapt to enterprise development need guidance.

\section{The Knowledge Economy Era in Our Country the Status Quo of Human Resource Management}

Since the economic system reform, human resource development has made great achievements in our country, at the same time, human resource development in economic integration of the world, there are still some defects, in our country. Mainly manifested in the following aspects: the growth of the national education funds is slow compared to the international education investment is still very weak. Since the economic reform, China's education funds investment increased year by year, but the education investment as a share of GDP for three consecutive years of decline. At present, the \$2684, the per capita public education expenditure is 65.9 times of our country. China has $1.6 \%$ of the world of education funding, education training account for $21 \%$ of the population of the world education. In theory; Public education in our country's actual investment as a share of GDP is only about $2.5 \%$. Based education to improve education and training system performance for the first time. In order to adapt to the human resource demand of innovation ability and innovation ability of high-tech era, basic education in China were transformation from education for examination to quality education. At the same time, the development of higher education is of great significance for our country education system of training a large number of senior talent, develop a preliminary high school education changes the unreasonable structure of vocational and technical education in our country. With the development of economy and the improvement of people's income, expanding education financial channels. From the beginning of social groups and individuals, as the market competition mechanism of the income level of resident, improving, the consciousness of independent development of human resources and population residents rapid increment increased spending on education. Although the channels to expand education fund in our country, education and training system in the world competitiveness report arrangement of 43 have very big improvement, but on-the-job training, our country. In addition, the common "examination education", all kinds of students' training school score low energy intercommunity, difficult to adapt to the society, lack of innovation consciousness.

Citizens need to increase cultural life, but the cultural creative industry, the lack of high-quality talent. First invented in 1998, the British government "cultural creative industry" to describe the social production of the original term or creative, advocating "for innovation, as the source of knowledge, as the carrier, in order to create economic value as a target", they press, TV and radio, film and video, interactive, leisure, fashion design, the software and computer maintenance, software design, music, advertising, architecture, art, art and antiques, process and so on. The current our country employment difficulty of college students, some economists say the root cause is our country cultivate college students' creativity and work at the end of the low economic chain, thereby creating value than the developed countries, in the high-end professional choice is very high.

The world economic integration and the emergence of knowledge economy era, many countries to take a new human resources development strategy, to cope with the challenge of international competition. Taken together, in the following aspects:

Increased investment in human capital investment and high development. Due to the human capital to promote the development of economy, the western developed countries to increase consumption. For example, in the United States, the United States as the world's science and technology, economic and military power, and human capital investment can't be separated. 
American education fund is the world's largest, accounting for $15.8 \%$ of its fiscal expenditure, accounting for $8.6 \%$ of gross domestic product. Cultural industry is more than the aerospace and military industry, the first export output value of more than $20 \%$, in the United States, accounting for 18\% 25\% gross national product (GNP),; About 2.8 billion yen, the Japanese culture industry accounted for $14 \%$ of gross domestic product.

With the development of the western enterprise management organization structure of the smooth and the transformation of the enterprise employees value, more and more advanced management is no longer the only standard for vocational training. So, the most western European companies, when in addition to continue through the personnel management mechanism also accompanied by the introduction of the constructive using traditional methods such as training, employment promotion, rich or increase work, content to human resource development, employees will feel more challenging work; As far as possible for the staff to provide more rotation. Therefore, the implementation of human resource development methods should be three-dimensional, multi-dimensional.

\section{Human Resources Management Innovation Countermeasures}

Due to the small and medium-sized enterprise is small, less operators, in its leadership not invest enough focus of human resource management, the cost of employees, and managers think the impact is not big, hired more easily. This understand their contribution to the long-term development of the enterprise is not easy to cause the enterprise talent interruption and lack of key talent, and, on the other hand, lead to enterprise production disruptions. So, from the long-term development of the enterprise's perspective, enterprises should establish and perfect human resource management and to consider, the enterprise only depend on the number of employees and master the key, high-end technology talent will accelerate the progress and development of the enterprise.

Setting scientific selection and employment mechanism and selection system, outstanding ability, for the best talent reward and promote, in order to encourage and improve staff work enthusiasm, may also attract foreign talent. We will strictly control and avoid the use of contact improvement or reward, otherwise it will lead to enterprise staff's work enthusiasm, to achieve the value of their own employees not recognized, and note that it will lead to enterprise talent loss, especially to key personnel lost key technology, it will lead to huge losses to the enterprise. Company leaders and managers must be importance to the environment of the enterprise, to provide a good atmosphere for employees, and learning environment, enterprise's value.

Effect of a kind of system must be with the specific enterprise development stage, the economic and social policy environment, personnel quality and management level. Because of the differences between different enterprises in all aspects, in the success of an enterprise human resource management system, in the other companies can not play a good forecast effect. Therefore, draw lessons from successful enterprises human resources management system, should be careful analysis successful enterprise human resources management system play a role of specific environmental conditions, the characteristics of background, human resource management system and specific environmental conditions, the relevance of the characteristics of the background, on the basis of judging the enterprise human resources management system to build the basic train of thought. Enterprise human resources management system to success in clear the specific environmental conditions play a role, background characteristics, on the basis of employee job satisfaction survey should be used, organizational morale survey, interview and literature analysis methods such as serious diagnostic analysis of the enterprise human resources management environment and the status quo, to determine the specific environment of the company and 
successful business condition, whether background characteristics have gay? If similar, we can draw lessons from successful enterprise human resources management system. Continuous improvement through the establishment of enterprise culture, enterprise staff with enterprise common development, make the enterprise personnel for the enterprise development and continuous efforts, continuous innovation. In a real culture promote the recognition of enterprise value, in order to promote the long-term development of the enterprise. Thus personalization is adapt to the characteristics of the enterprise human resources management system.

\section{Conclusion}

Knowledge and technology innovation is an important source of human economic and social development. Knowledge economy is injected more robust to China's economic development and social development, the better chance. The knowledge economy era for the survival of the new economic era means knowledge production resources and knowledge. In the new economic era, human capital is not only physical capital and natural capital, but in order to create a source of wealth and economic growth, the development of knowledge economy is advantageous and optimizing economic structure, a reasonable use of resources, protect the ecological environment, promote the coordinated development, improve the quality of our population and eliminate poverty, and so on, is advantageous to the national innovation system construction in the new century. Enterprise human resources management of the knowledge economy era, often only in concept, methods and means, form and method innovation, keep the change of era pace, give full play of human resource management strategy, real people orientation and goal for training and the role of human resource development.

\section{References:}

[1] quoc hai. tran Employee training and development, theory application in employee training and development, tsinghua university press, 2012 (03) : 169-179.

[2] yu-hang wang. Knowledge economy and the talent quality [M] talent cultivation, zhejiang university press, 2009 (9). 111-116

[3] deng yl, get, XiGongHua. Knowledge staff incentive mechanism research, knowledge staff incentive contract relationship, southeast university press, 2011 (9) : 89-152.

[4] Fuhuan Liu Jianfeng. Ye , built by the China human resources development work standard traction training system 2010 (09) 41-45.

[5]Daniel chan. The capital market and the adjustment of industrial structure, knowledge economy and the structure upgrade 2008 (09).12-19. 